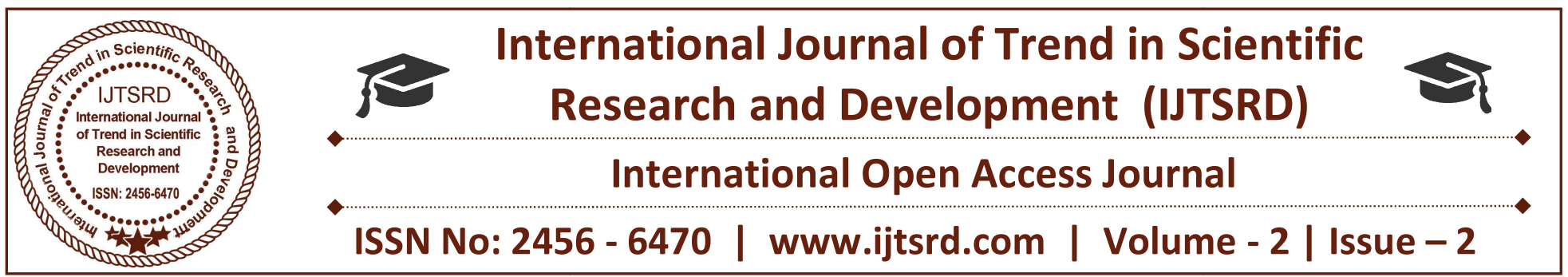

\title{
Representation of the Perverted Politics: A Study of Anurag Mathur's The Department of Denials
}

\author{
Dr. Anshu Sailpar \\ Assistant Professor, Department of English, Ch. Devi Lal University, Sirsa, Haryana, India
}

\begin{abstract}
Politics is a game of power and the power plays a significant role in molding relation in society. Power exists everywhere and in every relationship too. A person is constantly subjecting it and being object of it. In other words, power is the basis that ensures the inter-personal relationships amongst human beings. It highlights, then, the hegemony or the hierarchical states in the relationships. Even in the postrevolutionary world attributed by ideal classless society, power is in its existence in certain forms such as the power of possessing knowledge, or the power of dominating someone in making good arguments in any meeting. It may be said that power is the ability to bring a change in society or in the behavior of an individual that may be positive or negative one. The present paper is an attempt to show Anurag Mathur's perfect handling of representing the perverted politics in his novel The Department of Denials.
\end{abstract}

Keywords: Power, Politics, Hierarchy, Hegemony, Power relations

George Orwell in his famous novel, Nineteen EightyFour observes, "Power is not a means; it is an end. One does not establish a dictatorship in order to safeguard a revolution; one makes the revolution in order to establish the dictatorship. The object of persecution is persecution. The object of torture is torture. The object of power is power" (234). Thus, Orwell indicates through this quote that the aim of a powerful person is to become more powerful. The Department of Denials, written by Anurag Mathur in 1998 is one of the interesting novels illuminating the author's satirical and humorous nature. It clearly depicts the corrupt political system of India in the delineation of which Anurag Mathur is obviously not an exception. Contemporary Indian literature has become mature enough to reinvent and reclaim our enriched past. Many Indian writers have highlighted the falling moral values in the Indian society in the post-independence era through their writings. They have indulged themselves in evaluating the Indian society from historical, social, political, cultural and economic perspectives. The Indian writers intended to hit upon the Indian political system have largely been sarcastic in their treatment. They take the support of different satirical tools to hit upon the prevalent vices and frivolities in the system. They have developed a kind of literary vibrancy and worth to expose the socio-political system with vicious and kind frankness. Anurag Mathur too is one of them who have successfully taken into consideration our Indian political system. His works enable us to widen and direct our thoughts to the pertinent problems that truly affect the Indian sensibility and its belief system. He has attacked the political system that shows how politicians use their power to exploit their subordinates.

At the outset, Anurag Mathur entitled his novel The Department of Denials as 'Are All Women Leg Spinners?' asked the Stephanian. But later in 2004, he chooses the title as The Department of Denials that runs on the political tract in general and the identity quest of one of the major characters Babar Prasad Thakur in particular. Like all great epic heroes, he starts his journey alone. Though his father $\mathrm{Mr}$. Bahadur Prasad Thakur is an influential honest 
bureaucrat (Joint Secretary in Income Tax Department), he too has to face the mischiefs of netas and babus. It is only his father's honesty that brings problems to him and that sounds too ironical. The author speaks about him:

His subordinates regarded it as frighteningly abnormal. His wife regarded it as suicidal. But so far, most people had overlooked it as the eccentricity of an extremely competent, exceptionally hard working, but somewhat quiet and self-effacing officer. If he was intent on being peculiar, most people who dealt with him felt, that was his business. But no one ever doubted his knowledge, his ability, or even his genuine humaneness especially in a career where nearly every single file he dealt with was a pack of lies. (TDOD 6)

The novel begins with the fancies of Babar Thakur who is an aspirant to be the Prime Minister of India one day. He says to his friend Jeet Lamba, “. . . am going to become the prime minister of India" (1). It shows his thrust for power. His friend invariably makes fun of his dreams and comment always in a mocking manner: "Great Idea,' I'll handle the women wing. Think of it" (2). Like any Shakespearean hero, Babar wishes to "blaze the trail, the other will follow and we [Babar and his friend Jeet Lamba] dominate the entire Indian firmament. We won't just be the stars, we'll be the suns and India will revolve around us" (2). This shows that Babar Thakur thinks too much about the dreams and determined to fulfill the dreams. The main political ground of the novel starts with the political intentions, dreams, and fancies of Babar Thakur that slowly and gradually develops to his father's miserable condition amongst corrupt politicians like Balak Kumar. The author has given a sway to the wishes of Babar Kumar that gives a jerk to his father Bahadur Prasad Thakur. It shows that it is very difficult, to be honest in the corrupt system. The novel attacks the corrupt system of India where powerful corrupt people influence honest people.

Anurag Mathur, as a multifarious writer, not only discusses problems related to political system but also the associated problems. The present novel is a fine blending of multi aspects of Indian socio-political system. An incident of Meeta Devi Ji, a theatre artist bewilders the honest officer at first instance. The novel seems to be a constant fight between an honest officer and corrupt system. The theatre artist Meeta Devi gets into trouble for "being suspiciously understated by the assessing officer who had ordered high fines to be imposed" (TDOD 6). Mukund Gupta, an assistant to the minister Balak Kumar makes a call to Bahadur Prasad to take care of Meeta Devi ji. He asks him: “'Please do look after her case,'. . . 'Some units and Indira Vikas Patras were found during an income tax raid on her premises, and that created the trouble. It's just a small matter" (7). It is quite ironical that ministers take the side of guilty people and there is nothing serious if they commit anything wrong. The theatre artist gets freed herself by being the follower of ministers but she gets into trouble again when Sunita Pandhi, an environmentalist puts the charge against her for being the cause of Cobra's psychiatric stress as Meeta Devi's stage show was given the title "Ms. Curvaccous Cobra" (7). Though it sounds quite absurd that the theatre artist becomes the reason for Cobra's stress, it indirectly reveals the writer's intention to hit upon the petty Indian politics. The guilty like Meeta Devi free themselves from the clutches of law and order because of having the protection of powerful ministers. The powerful ministers like Balak Kumar take undue advantage of their power and hence gives a blow to crimes in the society. The arguments and counter-arguments from Balak Kumar and Sunita Pandhi bring out the abhorrent picture of Indian political system. Balak Kumar at zero hours in the parliament gives explanation very plaintively. On the other hand, Sunita Pandhi in a press conference tries to prove the minister wrong. Finally, she busted out by unveiling the intimate relationships between Balak Kumar and Meeta Devi. This truly reveals the vicious reality of Indian politics and its runners. She asserts:

'I have personally spoken to hotel employees in Bombay who have seen this woman visit our distinguished minister in his suite while carrying a bag that most certainly must have contained the unfortunate snake. What my group would like to know is, what was she doing visiting Mr. Kumar at night? And how dare he imply that he does not know her?' (9)

Her logic is strong but carries no solid proofs and hence discarded. The power follows authority and this becomes discernible through the portrayal of Balak Kumar. But very cunningly Balak Kumar gets himself freed from the allegations put forth by Ms. Pandhi. Balak Kumar gets the idea that the man behind income tax raid against her favourite Meeta Devi alias Ms. Bite is Mr. Thakur who is flawlessly honest. Thinking that Mr. Thakur can be problematic for him in future, he decides to transfer him from his existing 
office. In the guise of a helping hand for the public, he decides to teach a lesson to Mr. Thakur indirectly. At a place, one senior politician remarks, "we cannot say that we are teaching the fellow a lesson"" (19). Further, it is decided that in order to redistribute the work of several ministries, all responses would be centralized under one authority whose job would be to collect all the information from the sources and issue the notification as well. This new office is basically created for Mr. Bahadur Thakur who is promoted to the rank of Secretary. Both Mr. and Mrs. Thakur get the idea that this is done as a sort of punishment to Thakur. Her wife exclaims, "They can do it you because no one is interested in protecting you. Face it. An honest bureaucrat in your position isn't going to have a trunkful of friends. And you don't have even one" (13-14). Her wife argues, "For years I've warned you, this is not the life in which you can stay honest. But did you listen? No. And now you're well and truly caught and you don't have a soul to turn to. All our life, me, the children, the family, we've lived dreading this moment. And now it's come" (14-15). Thus, Balak Kumar under power possession affects Mr. Thakur politically.

Michael Foucault seems convincing while talking about the concept of power in the relation to its subject and being the object. He opines that every individual uses power as subjecting it and being an object of it. For an instance, when a powerful boss shows his power to his subordinates, the latter is obviously an object of boss's power. Similarly, when the subordinates go on strike or join a union, he subjects his boss to the collective power that he and his co-workers possess. In the present novel, this power relation works at the most. The condition of Mr. Bahadur Prasad Thakur is pitiable who is being grinded under the power politics as used by Balak Kumar. The latter leaves no stone unturned to punish Thakur in one way or the other. The location of DODO (Department of Denial Office) does not suit to Thakur. It was not well furnished moreover. The text states the location thus:

Mr. Thakur sighed deeply and entered. On one side were the white urinals and toilet cubicles; on the other side of the wall had been placed a desk, chair, on the desk a jug of water covered with a white cloth with beads on it to weigh it down and two upturned glasses. Two files already awaited his attention. Even a telephone had been installed. (TDOD 17)
While meeting to Mr. Singh, the manager, Thakur says, "You Know I can't sit here" (18) but Mr. Singh says, "but I have ordered from very high up. Up and up and up" (18). Above all, Mr. Thakur is provided such a stenotypist who is "so incompetent, so inept" (20) who hardly understand anything. The "fearless artist was named Soma Sagar" (20). The text states about the talents of Soma Sagar thus:

If a draft typed by him was corrected for mistakes, he remedied those while making new ones. It was said that he personally responsible for the nervous collapse of no less than seven gazette officers. Since he had been hired on the basis of fulfilling the requirements of not just one but several quotas, he could not be fired without precipitating a constitutional crisis. The government really didn't know where to hide his talents, until Balak Kumar found him and sent him with his best wishes and blessings to Mr. Thakur in his new office. (TDOD 20-21)

Any organization is considered to be the political system where power is a key mechanism that influences the decisions and organizational outcomes. Here in the novel, the department of denials office is acting like an organization where Balak Kumar is the key mechanism to influence the decisions. It has been stated in this regard, "Every social act is an exercise of power, every social relationship is a power equation, and every social group or system is an organization of power" (qtd. in "An Introduction to the Comparative Politics"). The truth behind the veils of politics is invariably bitter. One who faces becomes averse to it. Perhaps that is why Bahadur Thakur advises his son not to join politics. Max Waber has rightly said that power is always authoritative or coercive in nature. This authoritative power is invariably used in the legitimate sense and everyone is bound to follow that. In the present novel, Balak Kumar, a minister uses his authoritative power and tries to influence others in one way or the other. In the context of authoritative power, the main characteristics of the politician should be taken into consideration.

A politician will always work with focused mind though that may turn into a designing one. He always tends to work with wearing a mask because his political career is a priority. He remains conscious of maintaining his image in public arena. His all policies and ideologies will be in the favor of his favorite people. They are certainly biased and overtly too. No 
communication can take place without a context. Therefore, through some medium biasedness may enter through an individual or a group who are associated with one another socially, politically and economically. The novel also displays a true picture of a politician through the portrayal of Balak Kumar who can make people dance to tune like a puppet. He tries to justify all his misdeeds and convinces public with the help of his double standards. When Balak Kumar feels that his reputation regarding the upliftment of women has been degraded, he tries to restore his image or the lost glory. He summons a virtual slave woman who has been made to work appalling hours and the victim of her landlord's lustful nature. Balak Kumar poses himself to be the savior of that lady and present her before the press in Delhi, at a conference. He shows himself to be the true well-wisher of that lady. The writer uses satirical language to describe the situation thus: "Some two dozen journalists eventually attended, and, if they were not genetically such a skeptical race, would have been quite moved by how the lady was kept locked in an airless room and beaten for no reason at all" (TDOD 66). Balak Kumar does not hint at his helping nature apparently but indirectly praises himself to be in limelight before media. He says, "The poor woman had no one of her own'. . . laughing at his own soft heart, 'but you know how I get when I hear of any injustice to the poor. My blood really boils"" (66). Balak Kumar's fake helping nature gets revealed clearly when his assistant pressurizes the victim (lady) to speak after him. It is quite clear by the questioning and the replying of the lady that it was all preplanned. The assistant asks sharply to the woman:

Didn't the minister rescue you? Say something.'

The woman nodded.

Didn't your owner ill-treat you and commit excesses on you?

She nodded again.

What would have happened if mantriji had not saved you? Would you be alive or dead?

'Dead,' she whispered.

'Speak louder' the assistant demanded.

'Dead,' she whispered again. (67)

The minister takes this opportunity as to prove himself the well-wisher of the lower section of the society, especially women. He tries to impress public by his adulated talks: "'I never seek any publicity for myself. But you must write that there are people in
India who are doing something for the upliftment of the downtrodden. I beg you with folded hands, don't print my name. But let people know and feel inspired that they too can do it. That is all I want"" (67). It is quite ironical that the same leader who talks so much of idealistic values about the upliftment of women exploits a woman sexually. The dramatic presence of the woman before journalists to show the generosity of Balak Kumar is found again in Balak Kumar's room in scandalous view. It goes in the text like: "Their second thought was that, despite her tousled hair and sleepy eyes, she looked somehow familiar. Then their gaze fell behind her and sprawled in a state of manifest exhaustion, bare-chested, at the very least, was the uplifter of the poor, Balak Kumar, the minister" (69).

Talking about the modern thinking of the power, it is found to be begun with the writings of Machiavelli and Thomas Hobbes. Their writings are considered the classics in the area of political writings. The former was in the favor of strategic and decentralized thinking about power and organization. According to him, power should be considered a means not a source. For the latter, it lies in hegemony. It is centralized and focuses on sovereignty. On the doctrine of the feeling of power, Nietzsche in The Gay Science says:

Benefiting and hurting others are ways of exercising one's power over them - that is all one wants in such cases! We hurt those to whom we need to make our power perceptible, for pain is a much more sensitive means to that end than pleasure: pain always asks for the cause, while pleasure is inclined to stop with itself and not look back. We benefit and show benevolence toward those who already depend on us in some way (that is, who are used to thinking of us as their causes); we want to increase their power because we thus increase our own, or we want to show them the advantage of being in our power - that way, they will be more satisfied with their situation. (38)

Here in the present novel, Machiavelli's ideal concept of power is partially applied as all the characters possessing power consider it not as a means but as a source. They indulge themselves in power game to grind their own axe. Similarly another political thinker i.e. Hobbes's philosophy too applies here. Power really resides in hegemony. Each character in the novel tries to impact his subordinates. In addition 
to this, Nietzsche's concept of the power too certainly fits into the framework of the present novel. Babar Thakur wants to be the PM of India in order to be the powerful man to execute his power over others. He assures Jeet, his friend to help him in various manners. Similarly, Bahadur Prasad Thakur also exercises his power. He is very honest a person. Being an honest officer, he gets the transfer from one office to the other that does not suit him. He is made to be the head of DODO (Department of Denial Office). In order to get the transfer from DODO, he misuses his power and tries to make Balak Kumar happy so that he may convince him for another transfer. He tries to justify even the misdeeds of Balak Kumar. Another character Meeta Devi too defends herself for being the favorite of powerful people. She gets freed herself by the influence of Balak Kumar from the allegations of Sunita Pandhi, an environmentalist. The wife of Bahadur Prasad too loves to enjoy the power and calls a spade a spade to the latter for being the real cause of his transfer. She advises her husband to be a bit crafty in order to be in the good books of authoritative people. One more character named as Sethji instigates Babar to be a powerful journalist who asks him to be in touch with another powerful man i.e. Mr. Sood, an American NRI. All these characters exercise their power either to get benefited by the powerful people or try to hurt others to influence others to show their own power. Thus, Nietzsche concept of power certainly fits into novel's framework.

Michael Foucault's concept of power seems apt to this novel. Foucault is of the opinion that power works at all levels and in all relations. There are multiple sources of resistance as power comes from multiple sources. Where there is power, there is resistance. The novel's story describes different perspectives of power relations through various characters. There is a shift from one episode to another episode though the main thread of the novel remains the same. The writer emphasizes on the politics that runs merely on the power possession. At the same time, he has also highlighted the youth's ambition to be the powerful personality through the character of Bahadur Prasad Thakur's son, Babar Thakur. At the very outset, he is found to be a dreamer of PM of India that, though, reduces to be a partial journalist only. For that purpose, he meets frequently Seth ji hoping for getting a better opportunity. Seth ji wants a powerful unbiased journalist who can "make the politicians shit in their pants" (TDOD 30). The personality of Sethji has been described in such a manner that may give him an impression of the powerful man: "He was virtually a dwarf, almost completely bald, with a shiny pockmarked face, gold-rimmed spectacles, he was dressed in a silk kurta and, inevitably, he was chewing paan" (29). It shows his dubious character as the one who talks about the "corrupt politicians who are killing the country" selects Mr. Sood who publishes a porn magazine named as Hustler in America. His proclivity towards Sood very much clears his character too. Moreover, his lady receptionist is enough to indicate his character who gives Babar "smiles as though recalling nights of perverted sexual calisthenics" (28). Afterwards, though, Seth ji rejects Mr. Sood too for being "softysofty" (73) as he wants some "hard-core journalists . . . who can make politicians really shit in their pants" (73).

The present generation of youth is a paradoxical generation in every sense due to the conservatism and liberalization policies of the Indian government. The urban young people are better educated and more technically sound and thus can play a better role in shaping up the future of India. But it is the most unfortunate thing that they do not know how to go about doing that. Moreover, they are, misled by politicians and other powerful people for their selfish ends and thereby reducing their willpower to do something for the betterment of the society. Young people are struggling hard to find work today. In the novel, both Jeet and Babar are the victims of 'lost generation' who try to lessen their anguish by sharing their deep feelings against the system that does not give them chance to pursue their goals. They get entangled in the power politics and thus make their distress and pain out from their hearts. Jeet wants to be a successful advertiser and Babar as PM at the first and a journalist later. Both guys are hampered by the web of power politics. When Jeet asks Babar about his dream of being a journalist, he grunts at Seth ji's tactics that keeps changing. On being asked by Babar to Jeet, he too reacts in the same manner:

'I got my first artwork thrown at my head by a client today. It's like the deflowering of the advertising bride. All account executives have to go through it.' 'Why did he throw things at you?' 'We were late. The client had to show these designs for a calender to his boss yesterday before he went abroad tonight, but we got late. Hence the flying Saucers.' 'You should have thrown them back.'Jeet snorted. 'Not in advertising. You just pick them up, and say "Thank you", go back to the office and bitch your head off. Somebody senior then 
complains to somebody senior there, but not enough to get your agency kicked off the account. Apologies are exchanged and life goes on.' (TDOD 75-76)

This conversation between the two clearly points out that the dreams of youth do not get enough space to flourish in. Power works everywhere that sometimes hinders them to go ahead towards their goals with a full pace.

In the present novel, the portrayal of Bahadur Prasad Thakur and Balak Kumar are complementary to each other. Both pertains their power to save each other. Each of them, according to Michael Foucault's concept of power, subjects the power and the other time being the object of it. Balak Kumar needs Bahadur to escape from the problematic situation as Bahadur always tries his best to give the best logic to conceal his misdeeds. Similarly, Bahadur Prasad comes handy to Balak Kumar so that he may get transfer from the DODO as soon as possible. The minister has been savored by Bahadur Prasad Thakur many a times leading Balak Kumar not to let him get transferred from the department of denials. There is Thakur's motive behind being so much good towards his minister Balak Kumar. Bahadur Prasad Thakur has to face the bad consequences of being good to minister. At a place, Bahadur Thakur saves Balak Kumar from media's questioning when he is found in Copenhagen amongst the nudists. His mind starts racing for composing an anticipatory denial. He faces media with the appropriate response to defend his minister: "'A Wholly scandalous and shocking misrepresentation of this completely innocent event is being put about. All of you who know the minister are fully aware that he would never participate in the sort of activities being suggested"' (TDOD 104). Bahadur Prasad Thakur gives an excuse that it all happened due to the cultural gap. He further asserts, "'Please, please, ladies and gentlemen, kindly let me share the reality. Please let me finish. The fact of the matter is that due to the cultural difference everyone has misunderstood his position completely'(105). The media starts giggling over the excuse given by Bahadur Thakur and once again he starts talking to media: " "the simple fact is that the minister was being visited by the conventions of nudists. These are very common in many parts of Europe and after repeated requests by them, and their assurance that they would help promote tourism to India, the minister kindly made time in his busy schedule and granted them an audience. Bahadur Thakur gives his best to prevent his minister from being alleged but media never leave any chance to put allegations on the character of Bahadur Prasad Thakur. The minister plays the game of power politics and the Bahadur Prasad Thakur plays the same on his part. Behind the veil of power, Balak Kumar, the minister does all wrong deeds and Bahadur Thakur uses his power to save his minister, the savior for being the head of the department of denials.

To Conclude, Anurag Mathur has very artistically represented all instances of perverted power politics in his present novel with the help of his powerful characters.

\section{Works Cited}

“An Introduction to the Comparative Politics.” Web. 15 May 2017.

$<$ http://essaymonster.net/politics/86012-an-introduction-to-the-comparative-

politics.html.>

Mathur, Anurag. The Department of Denials. New Delhi: Penguin, 1998. Print.

(All the subsequent citations to the text are also from the same edition and carry only the

page number in parenthesis immediately following the quotation and has been abbreviated as TDOD.)

Nietzsche, Fredrick. Ed. Bernard Williams. Trans. Josefine Nauphoff. The Gay Science.

Cambridge: $U$ of Cambridge P, Print.

Orwell, George. Nineteen Eighty-Four. London: Secar \& Warburg, 1949. Print. 